\title{
Influence of Cane Regulation ongrowth, Yield and Quality of Wine Grapes (Vitis vinifera L.)
}

\author{
Rani Shiranal*, Kulapati Hipparagi, S.N. Patil, D.L. Rudresh, Mallikarjun Awati, \\ G. Raghavendra and Satish Pattepur
}

Deparment of Fruit Science, College of Horticulture, Bagalkot, U.H.S., Bagalkot, Udyangiri- 587 104, Karnataka, India

*Corresponding author

\begin{abstract}
A B S T R A C T
Keywords

Cane regulation, Growth, Quality, Wine grapes, Yield

Article Info

Accepted:

05 January 2020

Available Online:

10 February 2020

A field experiment on "Qualities of wine as influenced by cane regulation and crop load of wine grape varieties grown under northern dry zone of Karnataka" was carried out during 2017-2018 at grape orchard, MHREC, UHS, Bagalkot. Among the varieties, Medika found to be superior over other varieties with respect to shoot length $(80.05 \mathrm{~cm})$, yield $(16.63 \mathrm{~kg} / \mathrm{vine})$ and total sugar $(21.09 \%)$. Vine regulated with 25 canes per vine exhibited superiority with respect to shoot length $(77.45 \mathrm{~cm})$ and total sugar $(20.87 \%)$ while, the vines with no cane regulation resulted into significantly the maximum yield ( $14.91 \mathrm{~kg} / \mathrm{vine})$ followed by vines with 40 canes per vine (13.46 kg/vine).
\end{abstract}

\section{Introduction}

Grape (VitisviniferaL.) is one of the most important fruit crops of the world, it belongs to the family Vitaceae. It is a commercially important sub-tropical fruit crop of peninsular India. Historically, it is grown mostly for wine making in the world over.

Due to limited domestic consumption of wine and non-availability of standard wine varieties to produce good quality wines of international standards, much emphasis was not given for research during previous decades in India. However, commercial wine grape production in India has begun only since 1980s. In India, wine grapes are being cultivated in an area of 13,200 ha (Anon, 2009).

Cane regulation is an essential form of pruning in vineyard operation. This is mainly done to regulate the current season growth, yield and quality of grapes. Crop load adjustment should be considered as one of the technical cultural practices suitable to modify grapevine physiology and plant production 
towards a defined goal (Mattii and Ferrini, 2005). Higher number of shoots per vine, i.e..increased shoot density impairs the productivity of shoots.

Therefore, fore pruning is done to develop shoots at this rate and their vigour may be curtailed by either pinching or thinning of shoots. Hence, cane thinning is considered as a technique which could lead to improvement in grape and in wine quality (Bravdo et al., 1985 and Lancono et al., 1991). Thus, it is clear that cane regulation plays a crucial role in the management of vine productivity and quality.

\section{Materials and Methods}

The present investigation was carried out during 2017-2018 at grape orchard, MHREC, UHS, Bagalkot to study the effect of cane regulation on growth, yield and quality of wine grapes. Cultural practices were uniform for all the vines, irrespective of the treatments as per the package of practices. The canes were regulated at four leaf stage after back pruning with secateurs.

Two main plot treatments and seven sub-plot treatments were replicated thrice. Five plants were taken for each replication and five shoots from each category under each treatment were selected at random and tagged for detailed observations.

The experiment was laid out in a split plot design with varieties as main plot treatments and cane regulation levels as sub-plot treatments.

The shoot length was measured from the base of the shoot on the cane to the growing point. The observations recorded after $30^{\text {th }}, 60^{\text {th }}$ and $90^{\text {th }}$ day of fore-pruning. The mean bunch weight was multiplied by average number of bunches per vine to get yield per vine and expressed in kilogram. The quality parameter like total sugar was recorded according to the standard procedures (Ranganna., 1977). The data collected on different parameters were subjected to statistical analysis (Panse and Sukhatme, 1967).

\section{Results and Discussion}

Data on length of the fruiting shoot as influenced by varieties, cane regulation and their interaction at $30^{\text {th }}, 60^{\text {th }}$ and $90^{\text {th }}$ day after fore pruning are presented in Table 1.

Significant difference was found among the wine varieties with respect to shoot length at $30^{\text {th }}$ day after fore pruning. Among the varieties, Medika $(41.25 \mathrm{~cm})$ recorded the highest shoot length, followed by Shiraz $(37.75 \mathrm{~cm})$ and the lowest was noted in Cabernet Sauvignon $(24.75 \mathrm{~cm})$.

At $60^{\text {th }}$ day after fore pruning, among the varieties, Medika $(71.92 \mathrm{~cm})$ recorded the highest shoot length, which was statistically similar with Shiraz $(69.55 \mathrm{~cm})$ and the lowest was recorded in Cabernet Sauvignon $(44.22 \mathrm{~cm})$. Similar results were also recorded at $90^{\text {th }}$ day after fore pruning.

This might be due to the genotypic vigorous character of Medika which in turn might have contributed for significant increase in length of the fruiting shoot and also may be due to positive interaction among the treatments with respect to shoot length.

According to Shikhamany (1983), vigour of the grape vine has been an important growth attribute for distinguishing different grape varieties.

The decrease in canes per vine led to significant increase in the shoot length at $30^{\text {th }}$, $60^{\text {th }}$ and $90^{\text {th }}$ day after fore pruning. 
Table.1 Length of fruiting shoot as influenced by cane regulation at 30, 60 and 90 days after fore-pruning in wine grapes Vitisvinifera L.)

\begin{tabular}{|c|c|c|c|c|c|c|c|c|c|c|c|c|c|c|c|}
\hline \multirow{3}{*}{ Treatment } & \multicolumn{15}{|c|}{ Shoot length (cm) } \\
\hline & \multicolumn{5}{|c|}{$30^{\text {th }}$ day } & \multicolumn{5}{|c|}{$60^{\text {th }}$ day } & \multicolumn{5}{|c|}{$90^{\text {th }}$ day } \\
\hline & $\mathrm{C}_{1}$ & $\mathrm{C}_{2}$ & $\mathbf{C}_{3}$ & $\mathrm{C}_{4}$ & Mean & $\mathbf{C}_{1}$ & $\mathrm{C}_{2}$ & $\mathbf{C}_{3}$ & $\mathbf{C}_{4}$ & Mean & $\mathbf{C}_{1}$ & $\mathbf{C}_{2}$ & $\mathbf{C}_{3}$ & $\mathrm{C}_{4}$ & Mean \\
\hline $\mathbf{V}_{1}$ & 21.67 & 24.67 & 25.33 & 27.33 & 24.75 & 40.00 & 44.28 & 44.61 & 48.00 & 44.22 & 50.64 & 56.01 & 56.50 & 63.89 & 56.76 \\
\hline $\mathbf{V}_{2}$ & 35.83 & 42.33 & 42.50 & 44.33 & 41.25 & 65.50 & 71.50 & 74.50 & 76.17 & 71.92 & 73.80 & 78.45 & 80.95 & 87.01 & 80.05 \\
\hline $\mathbf{V}_{\mathbf{3}}$ & 32.33 & 35.67 & 37.33 & 39.67 & 37.75 & 64.89 & 69.40 & 71.17 & 72.73 & 69.55 & 74.50 & 78.00 & 82.56 & 84.50 & 79.89 \\
\hline $\mathbf{V}_{4}$ & 21.50 & 26.17 & 26.83 & 27.67 & 25.54 & 53.00 & 54.92 & 55.79 & 58.78 & 55.62 & 69.50 & 71.67 & 72.50 & 75.50 & 72.29 \\
\hline$V_{5}$ & 31.50 & 37.00 & 38.50 & 40.33 & 36.83 & 61.23 & 67.07 & 66.62 & 68.06 & 65.74 & 68.50 & 72.68 & 75.61 & 77.06 & 73.46 \\
\hline $\mathbf{V}_{6}$ & 30.67 & 34.33 & 35.33 & 36.00 & 34.08 & 61.73 & 65.56 & 66.73 & 68.61 & 65.66 & 69.79 & 71.83 & 72.84 & 76.73 & 72.80 \\
\hline \multirow[t]{2}{*}{ Mean } & 28.92 & 33.36 & 34.31 & 35.88 & & 57.72 & 62.12 & 63.24 & 65.39 & & 67.79 & 71.44 & 73.49 & 77.45 & \\
\hline & \multicolumn{3}{|c|}{ S.Em \pm} & \multicolumn{2}{|c|}{$\mathrm{CD}(5 \%)$} & \multicolumn{3}{|c|}{ S.Em \pm} & \multicolumn{2}{|c|}{$\mathrm{CD}(5 \%)$} & \multicolumn{3}{|c|}{ S.Em \pm} & \multicolumn{2}{|c|}{$\mathrm{CD}(5 \%)$} \\
\hline $\mathbf{V}$ & \multicolumn{3}{|c|}{1.01} & \multicolumn{2}{|c|}{3.69} & \multicolumn{3}{|c|}{0.66} & \multicolumn{2}{|c|}{2.40} & \multicolumn{3}{|c|}{1.51} & \multicolumn{2}{|c|}{5.48} \\
\hline C & \multicolumn{3}{|c|}{0.32} & \multicolumn{2}{|c|}{0.95} & \multicolumn{3}{|c|}{0.43} & \multicolumn{2}{|c|}{1.28} & \multicolumn{3}{|c|}{0.48} & \multicolumn{2}{|c|}{1.43} \\
\hline $\mathbf{V} \times \mathbf{C}$ & \multicolumn{3}{|c|}{1.22} & \multicolumn{2}{|l|}{ NS } & \multicolumn{3}{|c|}{1.13} & \multicolumn{2}{|c|}{ NS } & \multicolumn{3}{|c|}{1.82} & \multicolumn{2}{|c|}{ NS } \\
\hline
\end{tabular}


At $30^{\text {th }}$ day after fore pruning, the vines regulated at 25 canes per vine recorded the maximum shoot length $(35.88 \mathrm{~cm})$ closely followed by 33 canes per vine $(34.31 \mathrm{~cm})$ and 40 canes per vine $(33.36 \mathrm{~cm})$ treatment, whereas, the lowest shoot length was registered in control i.e..without cane regulation treatment $(28.92 \mathrm{~cm})$.

Similar trend was also recorded at $60^{\text {th }}$ and $90^{\text {th }}$ day after fore pruning. It was obvious that the vigour of the individual shoot increased with increased severity of cane thinning which could be attributed to diversion of more metabolites to the canes and shoot. These findings are in line with the results obtained by Singhrot et al., (1977) in Thompson Seedless grapes and Bates (2008) in Concord grapes.

The interaction effects between varieties and the cane regulation levels on shoot length were found to be non-significant at $30^{\text {th }}$, 60th and $90^{\text {th }}$ day after fore pruning.

The data pertaining to yield per vine as influenced by varieties, cane regulation levels and their interaction are given in Table 2. The perusal of data revealed that the yield per vine was found to be significant with varieties.Medika registered the highest yield (16.63 kg/vine) which was on par with Shiraz (15.97 kg/vine) whereas the lowest yield per vine was obtained in Cabernet Sauvignon $(11.37 \mathrm{~kg} / \mathrm{vine})$.

The reason might be genotypic character of the Cabernet Sauvignon to bear smaller size of berries, with average of two seeds per berry and lesser number of panicles compared to Medika. These results were in accordance with Hachcholli et al., (2016) that among different genotypes of wine grapes, Grenache Blanc recorded the maximum number of panicles per vine (110.44) which contributed to the higher yield compared to Shiraz.

The yield per vine was significantly influenced by various levels of cane regulation. Among the various levels of cane regulation, the vines with no cane regulation gave significantly the maximum yield (14.91 $\mathrm{kg} / \mathrm{vine}$ ) followed by vines with 40 canes per vine (13.46 kg/vine). The lowest yield was recorded in vines regulated at 25 canes per vine $(11.83 \mathrm{~kg} / \mathrm{vine})$.

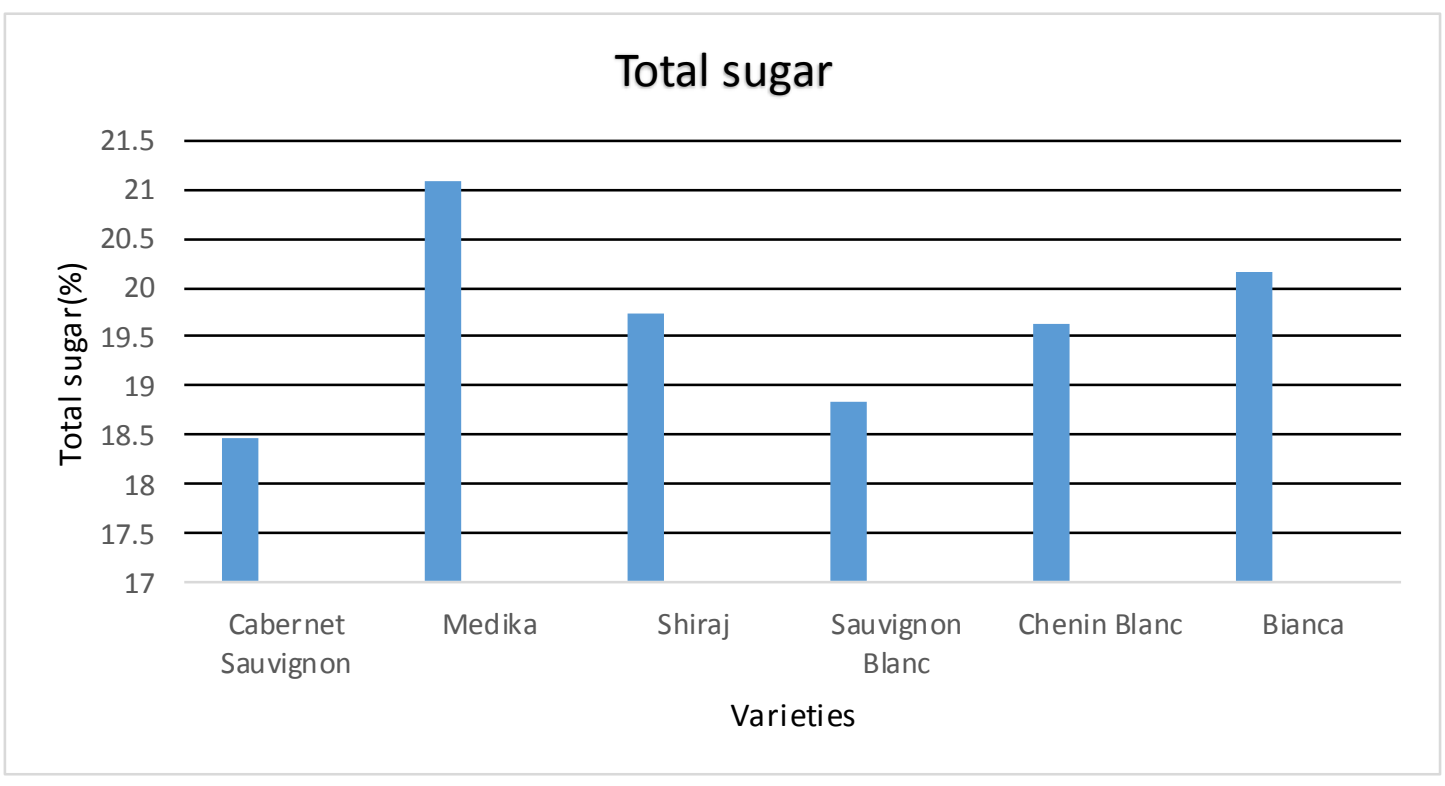

Fig.1 Total sugar of berries as influenced by Varieties 
This was mainly due to the presence of more number of bunches per vine that resulted in significant increase in total fruit weight compared to the cane regulated vines. Similar results were reported by Chougule (2004) in Thompson Seedless grape vine and they recorded that, the highest yield per vine $(15.96 \mathrm{k} \mathrm{g})$ was recorded with a cane density of 35 per vine.

However, the low yield per vine $(8.43 \mathrm{k} \mathrm{g})$ was registered in cane density of 30 per vine. The interaction effect between varieties and levels of cane regulation was found to be nonsignificant on yield trait. However, the highest yield was recorded in Medika vines with no cane regulation treatment (19.36 $\mathrm{kg} / \mathrm{vine}$ ) and the lowest was recorded in Bianca variety regulated at 25 canes per vine (9.05 kg/vine).

Significant variability was recorded among the varieties and cane regulation but interaction showed non-significant with respect to the total sugar of berries are given in Fig.1. With respect to the varieties, the pooled data indicates that the variety Medika recorded the maximum total sugar $(21.09 \%)$ which was significantly superior to the other varieties and was followed by Bianca $(20.16 \%)$ which was on par with Chenin Blanc (19.64\%).

On the other side, the minimum total sugar was recorded in the variety Cabernet Sauvignon $(18.45 \%)$ which was on par with Sauvignon Blanc (18.83\%).

With respect to cane regulation, the highest total sugar was recorded in vines regulated at 25 canes per vine $(20.87 \%)$ followed by 33 canes per vine $(20.05 \%)$, while, the minimum was recorded in vines with no cane regulation.

These findings are strongly supported by the findings of Joon and Sing (1983) and they reported that, sugars of grape juice increased with increased intensity of cane regulation levels. Similar findings were reported by Chadha and Harish (1970) in Perlette grapes. The interaction effect of varieties and cane regulation was not significant.

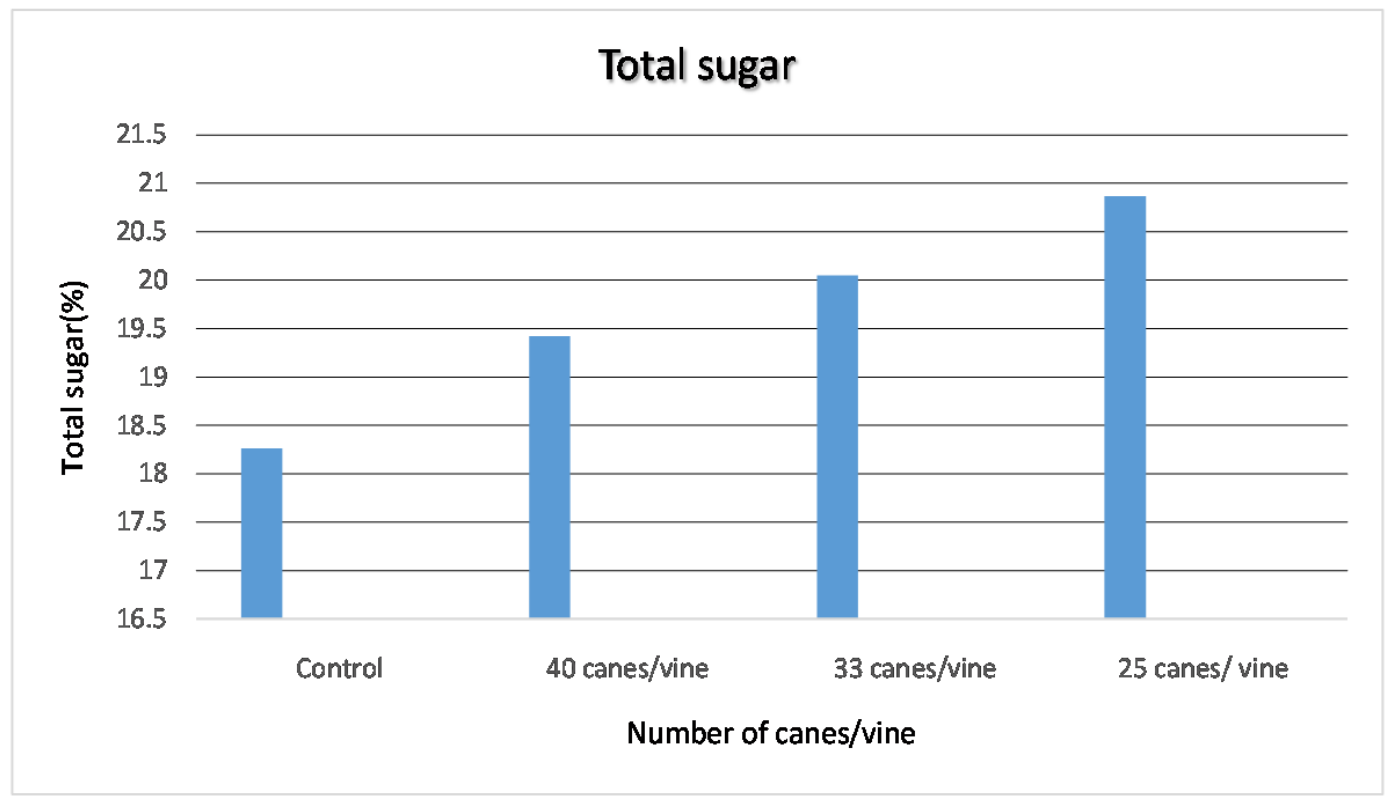

Fig.2 Total sugar in wine grapes (VitisviniferaL.) as influenced by cane regulation 
Table.2 Yield in wine grapes (VitisviniferaL.) as influenced by cane regulation

\begin{tabular}{|c|c|c|c|c|c|}
\hline \multirow{2}{*}{ Treatment } & \multicolumn{5}{|c|}{ Yield/vine (kg) } \\
\hline & $\mathbf{C}_{\mathbf{1}}$ & $\mathbf{C}_{\mathbf{2}}$ & $\mathbf{C}_{\mathbf{3}}$ & $\mathbf{C}_{\mathbf{4}}$ & Mean \\
\hline $\mathbf{V}_{\mathbf{1}}$ & 12.86 & 11.16 & 10.91 & 10.54 & 11.37 \\
\hline $\mathbf{V}_{\mathbf{2}}$ & 19.36 & 16.07 & 16.02 & 15.08 & 16.63 \\
\hline $\mathbf{V}_{\mathbf{3}}$ & 16.78 & 16.59 & 16.06 & 14.44 & 15.97 \\
\hline $\mathbf{V}_{\mathbf{4}}$ & 14.93 & 12.66 & 11.63 & 10.58 & 12.45 \\
\hline $\mathbf{V}_{\mathbf{5}}$ & 12.32 & 11.48 & 10.83 & 11.26 & 11.47 \\
\hline $\mathbf{V}_{\mathbf{6}}$ & 13.20 & 12.80 & 12.67 & 9.05 & 11.93 \\
\hline $\mathbf{M e a n}$ & 14.91 & 13.46 & 13.02 & 11.83 & \\
\hline & & $\mathbf{S . E m \pm}$ & & $\mathbf{C D}(\mathbf{5} \%)$ \\
\hline $\mathbf{V}$ & & 0.78 & & 2.83 \\
\hline $\mathbf{C}$ & & 0.31 & & 0.93 \\
\hline $\mathbf{V} \times \mathbf{C}$ & & 1.02 & & \multicolumn{3}{|c|}{ NS } \\
\hline
\end{tabular}

$\mathrm{V}_{1}$-Cabernet Sauvignon $\mathrm{V}_{2}$-Medika $\mathrm{V}_{3}$-Shiraj $\mathrm{V}_{4}$-Sauvignon Blanc $\mathrm{V}_{5}$-Chenin Blanc $\mathrm{V}_{6}$-Bianca $\mathrm{C}_{1}$-Control $\mathrm{C}_{2}-40$ canes/vine $\mathrm{C}_{3}-33$ canes/vine $\mathrm{C}_{4}-25$ canes/vine

Among the varieties, Medika found to be superior over other varieties with respect to shoot length $(80.05 \mathrm{~cm})$, yield $(16.63 \mathrm{~kg} / \mathrm{vine})$ and total sugar $(21.09 \%)$. Vine regulated with 25 canes per vine exhibited superiority with respect to shoot length $(77.45 \mathrm{~cm})$ and total sugar $(20.87 \%)$.

\section{References}

Anonymus, 2018, National Horticulture Board, Gurgaon.

Bates, T., 2008, Pruning level affects growth and yield of New York Concord on two training system. American. J. Enol. Vitic.,59(3): 276-286.

Bravdo, B., Hapner, Y., Loinge, R. C., Kohen, S. and Tabacman, H., 1985,
Effect of crop level and crop load on growth, yield, must and wine composition and quality of Cabernet Sauvignon. American J. Enol. Vitic., 36(2): 125-131.

Chougule, R.A., 2004, Studies on sub-cane pruning and cycocel application in relation to the canopy management in grapes. M.Sc., Thesis submitted to MPKV, Rahuri.

Hachcholli, A., Hipparagi, K., Rani, S., Ravindranath and Balesh, G., 2016, Evaluation of wine grape varieties for growth and yield under northern dry zone of Karnataka. Indian J. Sci. Res.,5(2): 409-411.

Joon, M.S. and Singh, I.S., 1983, Effect of intensity of pruning on ripening, yield 
and quality of Delight grapes. Haryana. J. Hort. Sci., 12(1-2): 44-47.

Lancono, F., Bertamini, M. and Scienza, A., 1991, LI Diradamento dei grappoli nella vine quale esemplificazione dei rapport tra fisiologia e tecnica colturale. Vegnevini, 18(10): 23-29.

Mattii, G.B. and Ferrini, F., 2005, The effects of crop load on Sangiovese grapevine. ActaHort., 689: 239-242.

Panse, V.S and Sukhatme, P.V., 1967, Statistical methods for agricultural workers.( $4^{\text {th }}$ Ed.). Indian Council of Agricultural Research, New Delhi. pp. 70-72.
Ranganna, S., 1977, Manual of analysis of fruit and vegetable products, Tata McGraw- Hill publishing company limited, New Delhi, India.

Shikhamany, S.D., 1983, Effect of time and different doses of Nitrogen and Potassium on growth, yield and quality of Thompson Seedless (VitisviniferaL.). Ph.D., Thesis submitted to UAS, Bangalore, Karnataka.

Singhrot, R.S., Singh, J.P. and Gupta, O.P., 1977, Effect of pruning levels on productiveness of Thompson Seedless cultivar of grape (VitisviniferaL.). Haryana J. Hort. Sci., 6(1-2): 37-40.

\section{How to cite this article:}

Rani Shiranal, Kulapati Hipparagi, S.N. Patil, D.L. Rudresh, Mallikarjun Awati, G. Raghavendra and Satish Pattepur. 2020. Influence of Cane Regulation ongrowth, Yield and Quality of Wine Grapes (Vitis vinifera L.). Int.J.Curr.Microbiol.App.Sci. 9(02): 440-446.

doi: https://doi.org/10.20546/ijcmas.2020.902.054 